\title{
Growth Performance, Organ Weights and Some \\ Blood Parameters of Replacement Laying Pullets Fed with Increasing Levels of Wheat Bran
}

http://dx.doi.org/10.1590/1516-635x1703347-354

\section{-Author(s)}

\section{Martínez $Y^{\prime, I}$}

Carrión Y"

Rodríguez R"

Valdivié M"II

Olmo C"

Betancur CII

Liu G'

Al-Dhabi NA ${ }^{\prime \prime}$

Duraipandiyan VIV

Scientific Observing and Experimental Station of Animal Nutrition and Feed Science in South-Central, Ministry of Agriculture, Hunan Provincial Engineering Research Center of Healthy Livestock and Poultry, Key Laboratory of Agro-ecological Processes in Subtropical Region, Institute of Subtropical Agriculture, Chinese Academy of Sciences, Changsha, Hunan 410125, China.

" Centro de Estudios de Producción Animal, Universidad de Granma, Apartado Postal 21. Bayamo, Granma. Cuba. C. P. 85300.

III Instituto de Ciencia Animal, Apartado Postal 24, San José de Las Lajas, Mayabeque, Cuba.

Iv Department of Botany and Microbiology, Addiriyah Chair for Environmental Studies, College of Science, King Saud University, P.O.Box.2455, Riyadh 11451, Saudi Arabia.

\section{Mail Address}

Corresponding author e-mail address

Gang Liu

Institute of Subtropical Agriculture

Chinese Academy of Sciences

Changsha, Hunan 410125, China

E-mail: gangle.liu@gmail.com

\section{-Keywords}

Growth performance, organ weight, blood parameter, pullet, wheat bran.

\section{ABSTRACT}

This study was conducted to determine the growth performance, organ weights, and selected blood parameters of replacement laying pullets (development phase) fed increasing levels of wheat bran (WB). A total of 24070 -d-old White Leghorn pullets (Hybrid $L_{33}$ ) were evaluated for seven weeks. Birds were assigned to three dietary treatments according to a completely randomized design. Treatments consisted of diets containing 100 (T1), 150 (T2), or $200 \mathrm{~g} / \mathrm{kg}$ (T3) of WB in partial replacement of corn, with 10 replicates per treatment of eight birds per replicate. Birds fed T2 presented higher body weight $(p<0.05)$ compared with T1 and T3 (1112.52 to $1163.35 \mathrm{~g})$. Also, T2 birds presented higher methionine plus cystine intake relative to $T 1(0.38$ to $0.40 \mathrm{~g} /$ bird/day). Likewise, a higher inclusion of WB $(200 \mathrm{~g} / \mathrm{kg})$ increased crude fiber (2.29 to $2.63 \mathrm{~g} / \mathrm{bird} /$ day) and crude fat (1.98 to $3.58 \mathrm{~g} / \mathrm{bird} /$ day) intakes $(p<0.05)$. However, the experimental treatments did not affect the relative weight of the organs or small intestine and cecum length ( $p>0.05)$. Serum concentration of triacylglycerols, cholesterol, calcium, phosphorus, hematocrit, or hemoglobin levels were not significantly different $(p>0.05)$ among treatments. These findings indicate a beneficial effect of use of $150 \mathrm{~g} / \mathrm{kg}$ of wheat bran on the growth performance of pullets during the development phase; however, the inclusion of this cereal up to $200 \mathrm{~g} / \mathrm{kg}$ had no effect on organ weights and blood parameters.

\section{INTRODUCTION}

The high costs of the conventional raw materials caused by the boom of the production of biofuels and by the global economic crisis (Aho, 2007; Gorter et al., 2013) has affected animal production, especially the poultry industry, where the feeds represent between 60 to $70 \%$ of the total production cost. Corn is the main source of ethanol in some countries and, although FAO (2013) reported that corn prices have been stabilized by the increasing production of this cereal, the prices are still very high and not profitable for poultry industry. Therefore, developing countries have had to seek alternative feeds for poultry, while maintaining product quality (Olmo et al., 2012), to compensate the negative effects of its higher prices and lower consumption (Aho 2007; Ali et al., 2008).

Wheat bran may be an economical and nutritional alternative for animal feeding in many tropical countries (Mateos et al., 2012). This feedstuff is a by-product of the dry milling of wheat and consists of the hard outer layer of the grains. It has adequate protein content for poultry and high crude fiber levels (106 to $136.3 \mathrm{~g} / \mathrm{kg}$ ) (NRC, 1994), but lower metabolizable energy content than many ingredients such as corn, sorghum, and barley (NRC, 1994). Research studies have shown 
the positive effects of the use of WB and its products, combined or not with enzymes, on the growth performance, intestinal microflora, harmful lipids, egg production, and digestibility of some nutrients in poultry (Ali et al., 2008; Courtin et al., 2008).

On the other hand, considering the increasing consumption of functional foods or nutraceuticals, dietary fiber has played an important role in human and animal nutrition (Eswaran et al., 2013). However, several studies with animals obtained contradictory biological responses of non-ruminant animals to dietary fiber. According to Savón et al. (2007), dietary fiber helps modulating the immune response in the gastrointestinal tract (GIT) by competitive exclusion. It increases the production of volatile fatty acids and reduces intestinal $\mathrm{pH}$, thereby increasing energy levels and reducing serum cholesterol. However, high levels of dietary fiber may increase digestible energy loss, reduce mineral utilization, and negatively affect the growth performance of broilers (González-Alvarado et al., 2007). In this sense, Mateos et al. (2012) reports that the effects of dietary fiber are related to its physiochemical characteristics, inclusion levels, feed physical form, and animal species and class.

In layer production, pullets are fed maintenance diets with low protein and amino acid diets during the development stage (10 to 16 weeks). The objective of this phase is to prepare these birds for egg production (NRC, 1994; UECAN, 2011). Nutritional strategies to increase dietary fiber (using mainly legumes and cereal brans) have been evaluated aiming at improving nutrient digestibility, growth performance, and future egg production (Savón et al., 2007; UECAN, 2011).

The objective of the present study was to determine the growth performance, organ weights, and blood parameters of replacement laying pullets during the development phase fed increasing levels of wheat bran partially replacing corn in the diets.

\section{MATERIALS AND METHODS}

\section{Birds, treatments, and housing}

This study was carried out according with Cuban guidelines for poultry husbandry and experimental protocol (UECAN, 2011).

In total, 240 70-d-old White Leghorn (Hybrid $\mathrm{L}_{33}$ ) pullets were evaluated for seven weeks. Birds were assigned to three dietary treatments according to a completely randomized design with 10 replicates per treatment and eight birds per replicate. Dietary treatments consisted of the inclusion of 100.00 (T1),
150.00 (T2) and $200.00 \mathrm{~g} / \mathrm{kg}$ (T3) of wheat bran partially replacing corn. Diets were formulated to supply the development pullets' nutritional requirements (UECAN, 2011) (Table 1).

Table 1 - Dietary ingredients and nutritional requirements (as fed) (10 to 16 weeks).

\begin{tabular}{|c|c|c|c|}
\hline \multirow[b]{2}{*}{ Ingredients $(\mathrm{g} / \mathrm{kg})$} & \multicolumn{3}{|c|}{ Experimental diets } \\
\hline & T1 & $\mathrm{T} 2$ & T3 \\
\hline Corn meal & 651.50 & 590.20 & 542.20 \\
\hline Soybean meal & 204.20 & 198.50 & 193.90 \\
\hline Wheat bran & 100.00 & 150.00 & 200.00 \\
\hline Soybean oil & 0.00 & 13.70 & 29.80 \\
\hline Salt & 3.00 & 3.00 & 3.00 \\
\hline DL-Methionine & 0.90 & 0.90 & 0.90 \\
\hline Dicalcium phosphate & 13.20 & 11.50 & 9.50 \\
\hline Calcium carbonate & 23.40 & 28.40 & 16.90 \\
\hline Choline & 0.80 & 0.80 & 0.80 \\
\hline Vitamin and trace element premix ${ }^{1}$ & 3.00 & 3.00 & 3.00 \\
\hline \multicolumn{4}{|l|}{ Calculated nutritional composition } \\
\hline Metabolizable energy (MJ/kg) & 11.72 & 11.72 & 11.72 \\
\hline Crude protein (g/kg) & 145.00 & 145.00 & 145.00 \\
\hline Calcium (g/kg) & 12.00 & 11.90 & 11.60 \\
\hline Available phosphorus $(\mathrm{g} / \mathrm{kg}$ ) & 4.20 & 4.00 & 3.70 \\
\hline Methionine plus cystine $(\mathrm{g} / \mathrm{kg}$ ) & 6.40 & 6.70 & 7.00 \\
\hline Lysine (g/kg) & 7.40 & 7.40 & 7.40 \\
\hline Choline $(\mathrm{g} / \mathrm{kg})$ & 0.40 & 0.40 & 0.40 \\
\hline Tryptophan (g/kg) & 1.70 & 1.70 & 1.70 \\
\hline Threonine $(\mathrm{g} / \mathrm{kg}$ ) & 5.60 & 5.60 & 5.60 \\
\hline Crude fat (g/kg) & 33.10 & 46.50 & 61.9 \\
\hline Crude fiber $(\mathrm{g} / \mathrm{kg})$ & 38.30 & 41.90 & 45.40 \\
\hline
\end{tabular}

'Provided per kilogram of diet: vitamin A, 75,00.0 IU; vitamin D, 12,00.0 IU; vitamin $E_{1} 7.50 \mathrm{mg}$; vitamin $\mathrm{K}_{3}, 2.1 \mathrm{mg}$; vitamin $\mathrm{B}_{2,2} 0.009 \mathrm{mg}$; thiamine, $0.50 \mathrm{mg}$; riboflavin, $4.00 \mathrm{mg}$; pyridoxine, $3.00 \mathrm{mg}$; pantothenic acid, $8.00 \mathrm{mg}$; niacin, $20.00 \mathrm{mg}$; biotin, $0.10 \mathrm{mg}$; folic acid, $0.40 \mathrm{mg}$; choline, $300.0 \mathrm{mg}$; manganese, $60.0 \mathrm{mg}$; zinc, $50.0 \mathrm{mg}$; iron, $60.0 \mathrm{mg}$; iodine, $0.80 \mathrm{mg}$; copper, $8.00 \mathrm{mg}$; selenium, $0.20 \mathrm{mg}$; cobalt, $0.50 \mathrm{mg}$.

Each replicate consisted of a metal cage measuring $80 \mathrm{~cm} \times 80 \mathrm{~cm}$. Feed and water were offered ad libitum in trough feeders and nipple drinkers, respectively. A lighting program of $12 \mathrm{~h}$ of natural light was applied. Sample size was calculated according to Font et al. (2007). Average relative humidity of $77 \%, 20.5^{\circ} \mathrm{C}$ average minimum temperature and $30.1^{\circ} \mathrm{C}$ average maximum temperature were recorded during the experimental period.

\section{Growth performance}

All birds were weighed at the start (70 days of age) and end of the experiment (119 days of age). Feed intake ( $\mathrm{g} / \mathrm{bird} /$ day) was measured daily during all the experimental weeks, and calculated as the difference between feed offer and feed residues. Livability was determined as the difference between the initial number of birds and recorded mortality. Tarsus length was measured using a sliding caliper. Nutrient and 
Martínez $\mathrm{Y}$, Carrión $\mathrm{Y}$, Rodríguez $\mathbf{R}_{\boldsymbol{t}}$ Valdivié M, Olmo C, Betancur C, Liu G, Al-Dhabi NA, Duraipandiyan V

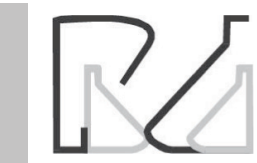

metabolizable energy intake were calculated according to their levels in the experimental diets (Table 1).

\section{Organ weights}

In week 16, when pullets were 119 days old, 10 birds per treatment were fasted for four hours and weighed in a digital scale (Sartorius model BL 1500). Birds were then bled by pincture of the jugular vein. The spleen, kidney, liver, proventriculus, gizzard, crop, small intestine, right cecum, left cecum, colon plus rectum, ovary, and oviduct were removed and weighed. The length of the small intestine and of the right and left ceca was measured (Martínez et al., 2013a).

\section{Blood parameters}

On the day of sacrifice, two $10-\mathrm{mL}$ blood samples collected from the jugular vein of 10 birds per treatment. One of the samples was collected in $20-\mathrm{mL}$ tubes and rested for one hour before centrifugation (Eppendorf centrifuge 5804, USA) at $10000 \mathrm{rpm}$ and $20{ }^{\circ} \mathrm{C}$ for 25 minutes for serum separation. The other sample (whole blood) was placed in 2-mL tubes and sodium heparin was added at a ratio of $2: 1$. Both samples were stored at $-20{ }^{\circ} \mathrm{C}$ until analyses in the laboratory.

Triglyceride, total cholesterol, calcium, and phosphorus levels were determined in the serum using commercial kits manufactured by Spinreact (Barcelona, Spain) and ultraviolet spectrophotometer (Humalyzer 2000, USA). Packed cell volume and hemoglobin were determined in the whole blood samples by the Wintrobe and Hemotest methods, respectively.

\section{Statistical analysis}

Data were submitted to analysis of variance (ANOVA) according a completely randomized design. Duncan's multiple range test was used to determine differences between means, using the statistical software SPSS, version 17.1

\section{RESULTS AND DISCUSSION}

The effects of increasing WB inclusion levels in the diet of replacement laying pullets (10 to 16 weeks of age) on livability, body weight (BW), tarsus length, feed intake, and nutrient and metabolizable energy intakes are presented in Table 2.

Pullet livability and tarsus length were not affected by dietary WB inclusion ( $p>0.05)$. However, the BW of T2 birds was higher compared with T1 and T3 (50.83 and $34.55 \mathrm{~g}$, respectively), at the end of the experiment
Growth Performance, Organ Weights and Some Blood Parameters of Replacement Laying Pullets Fed with Increasing Levels of Wheat Bran

$(p<0.05)$. Birds fed the T1 and T2 diets presented higher feed intake, as well as metabolizable energy, crude protein, lysine, calcium and available phosphorus intakes compared with T3 $(p<0.05)$, whereas the T2 and T3 diets promoted higher of methionine plus cysteine, crude fat intake, and crude fiber intakes as dietary WB increased $(p<0.05)$.

Table 2 - Growth performance in replacement laying pullets fed increasing levels of WB (10 to 16 weeks) ${ }^{1}$

\begin{tabular}{|c|c|c|c|c|c|}
\hline \multirow{2}{*}{ Items } & \multicolumn{3}{|c|}{ Experimental diets } & \multirow[b]{2}{*}{ SEM } & \multirow[b]{2}{*}{$p$-value } \\
\hline & $\mathrm{T1}$ & $\mathrm{T} 2$ & T3 & & \\
\hline Livability (\%) & 100.00 & 100.00 & 100.00 & & \\
\hline Initial BW (g) & 547.80 & 542.81 & 545.30 & 3.39 & 0.58 \\
\hline Final BW (g) & $1112.52^{b}$ & $1163.35^{a}$ & $1128.80^{b}$ & 9.15 & $<0.001$ \\
\hline Tarsus length (mm) & 101.65 & 102.18 & 101.33 & 0.30 & 0.14 \\
\hline $\begin{array}{l}\text { Feed intake } \\
\text { (g/bird/day) }\end{array}$ & $59.86^{a}$ & $59.67^{a}$ & $57.88^{b}$ & 0.39 & 0.006 \\
\hline $\begin{array}{l}\text { Metabolizable } \\
\text { energy intake } \\
\text { (MJ/bird/day) }\end{array}$ & $0.70^{a}$ & $0.70^{\mathrm{a}}$ & $0.68^{b}$ & 0.005 & 0.006 \\
\hline $\begin{array}{l}\text { Crude protein } \\
\text { intake (g/bird/day) }\end{array}$ & $8.68^{a}$ & $8.65^{a}$ & $8.39^{b}$ & 0.06 & $<0.001$ \\
\hline $\begin{array}{l}\text { Lysine intake } \\
\text { (g/bird/day) }\end{array}$ & $0.44^{\mathrm{a}}$ & $0.44^{\mathrm{a}}$ & $0.42^{b}$ & 0.003 & $<0.001$ \\
\hline $\begin{array}{l}\text { Methionine plus } \\
\text { cystine intake } \\
\text { (g/bird/day) }\end{array}$ & $0.38^{b}$ & $0.40^{\mathrm{a}}$ & $0.41^{a}$ & 0.003 & $<0.001$ \\
\hline $\begin{array}{l}\text { Calcium intake } \\
\text { (g/bird/day) }\end{array}$ & $0.72^{\mathrm{a}}$ & $0.71^{\mathrm{a}}$ & $0.67^{b}$ & 0.005 & $<0.001$ \\
\hline $\begin{array}{l}\text { Available } \\
\text { phosphorus intake } \\
\text { (g/bird/day) }\end{array}$ & $0.25^{a}$ & $0.24^{\mathrm{a}}$ & $0.21^{b}$ & 0.002 & $<0.001$ \\
\hline $\begin{array}{l}\text { Crude fiber intake } \\
\text { (g/bird/day) }\end{array}$ & $2.29^{c}$ & $2.50^{\mathrm{b}}$ & $2.63^{\mathrm{a}}$ & 0.017 & $<0.001$ \\
\hline $\begin{array}{l}\text { Crude fat intake } \\
\text { (g/bird/day) }\end{array}$ & $1.98^{c}$ & $2.78^{b}$ & $3.58^{\mathrm{a}}$ & 0.02 & $<0.001$ \\
\hline
\end{tabular}

The increasing levels of WB as a fiber source in the diets of development pullets (10 to 16 weeks of age) did not cause any morbidity or mortality. Savón et al. (2007), Ali et al. (2008), González-Alvarado et al. (2007), and Mateos et al. (2012) obtained similar results when using high levels of fiber-rich feedstuffs, supporting the use of WB in diets of development pullets, which have high fiber and low protein requirements (NRC, 1994; UECAN, 2011).

The higher body weight obtained in T2 may be due to the incorporation of the lipids present in soybean oil, which is rich in unsaturated fatty acids (Dänicke et al., 2000; Lefevre et al., 2012) and was not included in T1 (Table 1). According to Aguilar et al. (2011), the addition of unsaturated lipids in the diet reduces digesta transit rate, thereby increasing the digestibility of other dietary components. Furthermore, Rosebrough et al. 
(1999) and Latshaw (2008) reported that lipids can improve feed palatability by reducing dust formation and masking undesirable flavors, thereby increasing feed intake and body weight. This result demonstrates that unsaturated oils may be added to fiber-rich diets for replacement pullets, considering that these pullets should present adequate body condition at the onset of lay and aiming at reducing the incidence of vent prolapse (Martínez et al., 2013a).

On the other hand, WB has beneficial properties that may maximize growth performance. According to Jørgensen et al. (1996), when included at moderate levels in the diet, WB improves the growth performance, nutrient digestibility and microbial activity in broiler chickens. Also, Courtin et al. (2008) and Craeyveld et al. (2010) found that the dietary supplementation with WB arabinoxylooligosaccharides had prebiotic and competitive exclusion effects by increasing the intestinal colonization by Lactobacillus and Bifidobacterium and the production of shortchain fatty acids. Eeckhau et al. (2008) reported reduced Salmonella enteritidis colonization in broilers and Akhtar et al. (2012) demonstrated better immune response when WB was included in the diet.

The higher feed intake of T2 birds resulted in higher methionine plus cystine intake (Table 2), which may explain the higher body weight of T2 pullets. Sulfur amino acids function as methyl group donors in biochemical processes, promoting muscle protein synthesis, and are involved in detoxification and immune response of chickens (NRC, 1994). In this regard, Vieira et al. (2004) and Aguilar et al. (2011) reported that higher sulfur amino acid intake increased the growth performance and yield of edible portions, and decreased the abdominal fat deposition in broilers.

The inclusion of $200.00 \mathrm{~g} / \mathrm{kg}$ of WB (T3) reduced final body weight and the intake of protein crude, lysine, calcium, available phosphorus and metabolizable energy compared with T2, perhaps due to the higher crude fiber level (Table 1) and crude fiber intake (Table 2) obtained with T3. The T3 diet $(200.00 \mathrm{~g} / \mathrm{kg}$ of WB and $29.80 \mathrm{~g} / \mathrm{kg}$ of soybean oil) may have increased digesta volume, signaling satiety to the birds (Savón et al., 2007; Mateos et al., 2012). In this sense, Sacranie et al. (2012), feeding broilers with different fiber sources and increasing fiber levels, observed reduced feed intake. Indeed, Castanon et al. (1990) and Rodríguez et al. (2006) reported that increasing fiber levels reduced the feed intake and BW of laying hens. Furthermore, the higher soybean oil inclusion level (Table 1) determined higher crude fat intake in T3 birds
(Table 2), resulting in lower feed intake compared with $\mathrm{T} 1$ and $\mathrm{T} 2$. This may be related to a possible increase in the levels of the hormone leptin, which regulates long-term voluntary intake, in order to stabilize energy balance (Dridi et al. 2000; Martínez \& Savón, 2007).

The lack of BW differences between T1 and T3 (Table 2) may have been due to the fact that the experimental diets (Table 1) do not exceed the fiber limits $(100.00 \mathrm{~g} /$ $\mathrm{kg}$ ) recommended by the UECAN (2011). In addition, the higher intake of methionine plus cystine in T3 may have compensated the birds' BW compared with T1 (Table 2). Moreover, no negative symptoms of WB intake were observed in the present experiment. According to Hyatt et al. (2012), high WB levels may cause undesirable responses due to its high bulk, including laxative effects, as well as rancidity and the presence of WB phenolic acids, such as coumarins and ferulic acid linked to fiber (Shyama \& Muralikrishna, 2004).

Table 3 shows that the inclusion of increasing WB levels in the diet of replacement laying pullets (16 weeks) had no effect on the relative weight of the evaluated reproductive organs, immune tissues, digestive organs and viscera, or on small intestine and cecum lengths $(p>0.05)$.

Table 3 - Organ weights and intestinal length of 16-wkold replacement laying pullets fed increasing WB levels.

\begin{tabular}{|c|c|c|c|c|c|}
\hline \multirow{2}{*}{ Items } & \multicolumn{3}{|c|}{ Experimental diets } & \multirow[b]{2}{*}{ SEM } & \multirow[b]{2}{*}{$p$-value } \\
\hline & $\mathrm{T1}$ & $\mathrm{T} 2$ & T3 & & \\
\hline $\begin{array}{l}\text { Proventriculus } \\
\text { (g/kg of BW) }\end{array}$ & 0.45 & 0.38 & 0.40 & 0.05 & 0.62 \\
\hline Gizzard (g/kg of BW) & 3.33 & 2.94 & 3.14 & 0.20 & 0.43 \\
\hline Crop (g/kg of BW) & 0.55 & 0.40 & 0.42 & 0.04 & 0.07 \\
\hline $\begin{array}{l}\text { Small intestine } \\
\text { ( } g / k g \text { of } B W \text { ) }\end{array}$ & 2.60 & 2.07 & 2.06 & 0.21 & 0.16 \\
\hline Right cecum (g/kg of BW) & 0.21 & 0.19 & 0.21 & 0.03 & 0.89 \\
\hline Left cecum ( $\mathrm{g} / \mathrm{kg}$ of BW) & 0.24 & 0.21 & 0.20 & 0.03 & 0.63 \\
\hline $\begin{array}{l}\text { Colon plus rectum } \\
\text { (g/kg of BW) }\end{array}$ & 0.19 & 0.20 & 0.18 & 0.03 & 0.93 \\
\hline Spleen (g/kg of BW) & 0.19 & 0.20 & 0.16 & 0.02 & 0.42 \\
\hline Kidney (g/kg of BW) & 0.65 & 0.55 & 0.52 & 0.05 & 0.16 \\
\hline Liver (g/kg of BW) & 1.79 & 1.46 & 1.47 & 0.15 & 0.26 \\
\hline Ovary (g/kg of BW) & 0.07 & 0.05 & 0.08 & 0.01 & 0.26 \\
\hline Oviduct (g/kg of BW) & 0.09 & 0.06 & 0.07 & 0.03 & 0.73 \\
\hline \multicolumn{6}{|l|}{ Intestinal lenght } \\
\hline Small intestinal (m) & 1.04 & 0.93 & 0.96 & 0.06 & 0.42 \\
\hline Right cecum (m) & 0.12 & 0.13 & 0.13 & 0.008 & 0.97 \\
\hline Left cecum (m) & 0.13 & 0.13 & 0.12 & 0.009 & 0.75 \\
\hline
\end{tabular}

$(n=10 /$ group $)$

Eastwood (1992), Viveros et al. (1994), and Savón et al. (2007) reported that increasing levels of fiber in the 
Martínez Y, Carrión Y, Rodríguez R, Valdivié M, Olmo C, Betancur C, Liu G, Al-Dhabi NA, Duraipandiyan V

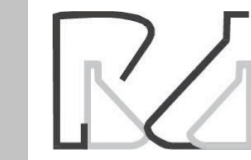

diet may increase cecum length due to a physiological adjustment to a longer permanence of digesta in this section. In this sense, González-Alvarado et al. (2007) and Martínez et al. (2010) found higher relative weight of the digestive organs and accessories when adding different fiber sources to broiler diets. Likewise, Rodríguez et al. (2006) reported higher relative weight and morphometry of the cecum of laying hens fed high-fiber diets.

The T3 diet (200.00 WB g/ $/ \mathrm{kg}$ ) contributed with $45.40 \mathrm{~g}$ of crude fiber $/ \mathrm{kg}$ diet (Table 1) and promoted a crude fiber intake of $0.34 \mathrm{~g} / \mathrm{bird} /$ day (Table 2); however, it was not sufficient to increase cecum weight and length compared with the T1 diet. These results are different from the findings of the authors mentioned above, who found heavier ceca in chickens fed diets containing higher fiber levels than those applied in the present study. The obtained gizzard relative weight also suggests that the fiber levels used in the current experiment were not high enough to change the weight of the digestive organs. In this sense, Hetland et al. (2003) reported that high-fiber diets cause an increase in the gizzard weight due to the fact that fiber is more difficult to grind than other nutrients and therefore accumulates in the gizzard.

On the other hand, the higher crude fat level and intake (Tables 1 and 2) obtained with the T2 and T3 diets, which contained soybean oil, may have influenced those results. As previously explained, the unsaturated lipids present in soybean oil may reduce the rate of intestinal transit (Aguilar et al., 2011), and therefore, may have counteracted the effect of fiber in the ceca. Moreover, because the crude fat intake was not excessive in the present experiment, liver relative weight and function were not affected (Okazaki et al., 2006). According to Connor et al. (1969), lipid digestion and transport to the liver in poultry greatly differs from mammals, especially cholesterol, which is stored in the liver of newly-hatched chicks, whereas it is stored in brain of newly-born mammals. Similar results were reported by Cherry \& Jones (1982), Aguilar et al. (2011), and Martínez et al. (2013b), when including high concentrations of polyunsaturated fat in the diets of the chickens.

The spleen is the main immune organ of laying pullets, and its relative weight was not affected by the treatments. Rodríguez et al. (2006) and GonzálezAlvarado et al. (2007) did not observe any changes in the relative weight of this organ in laying pullets and broilers, respectively, fed different fiber sources. During the development phase (10 to 16 weeks of age), the immune system of laying pullets is stable and it is
Growth Performance, Organ Weights and Some Blood Parameters of Replacement Laying Pullets Fed with Increasing Levels of Wheat Bran

characterized by the involution of the thymus and the bursa of Fabricius (Martínez et al., 2013a).

In the present experiment, dietary WB inclusion and levels did not influence the relative weight of the reproductive organs (ovary and oviduct). Similar results were reported by Castanon et al. (1990), Rodríguez et al. (2006) and Savón et al. (2007).

In the present experiment, blood cholesterol, triglyceride, phosphorus, calcium, hemoglobin, and hematocrit values of the laying pullets, as measured when birds were 16 weeks old, were not affected by increasing WB levels in the diets ( $p>0.05$ ) (Table 4).

Table 4 - Evaluated blood parameters of replacement laying pullets fed increasing WB levels (16 weeks of age).

\begin{tabular}{llllll}
\hline \multirow{2}{*}{ Items } & \multicolumn{3}{l}{ Experimental diets } & & \\
\cline { 2 - 4 } & T1 & T2 & T3 & SEM & p-value \\
\hline Hematocrit $(\mathrm{u} / \mathrm{L})$ & 0.33 & 0.35 & 0.36 & 0.02 & 0.56 \\
Hemoglobin $(\mathrm{g} / \mathrm{L})$ & 107.50 & 105.00 & 102.00 & 5.42 & 0.64 \\
Cholesterol $(\mathrm{mg} / \mathrm{dL})$ & 102.85 & 113.59 & 117.65 & 12.74 & 0.71 \\
Triglycerides $(\mathrm{mg} / \mathrm{dL})$ & 73.30 & 67.98 & 67.54 & 7.99 & 0.85 \\
Phosphorus $(\mathrm{mg} / \mathrm{dL})$ & 1.16 & 1.24 & 1.54 & 0.42 & 0.79 \\
Calcium (mg/dL) & 3.71 & 3.76 & 3.76 & 0.12 & 0.95 \\
\hline ( $\mathrm{n}=10 /$ group) & & & & &
\end{tabular}

The inclusion of WB in the diets did not influence hematocrit or hemoglobin values. Savón et al. (2007) and Martínez et al. (2010) reported similar responses in growing chickens fed different fiber sources.

Our results are consistent with the findings of Cherry \& Jones (1982) and Rieckhoff et al. (1999), who did not observe any reduction of blood cholesterol values when feeding WB to laying pullets and hamsters, respectively, as well as with those reported by McNaughton (1978), who did not detect any serum cholesterol changes when increasing fiber level in the diet of laying hens.

On the other hand, Kahlon et al. (1998), Kahlon et al. (2006), and Ali et al. (2008) reported a reduction in blood cholesterol levels when WB was added to the diets. According to Savón et al. (2007), dietary fiber reduces cholesterol absorption by binding with bile salts in the gastrointestinal tract, reducing intestinal transit time and increasing sterol excretion in the feces. Likewise, Savón et al. (2007), and Aguilar et al. (2011) found a lower blood levels of this lipid in broilers fed with high-fiber diets. This indicates that fiber levels higher than those used in the present experiment $(38.30$ to $45.40 \mathrm{~g} / \mathrm{kg}$ ) are needed to reduce serum cholesterol.

Despite the numerical reduction of serum triglyceride levels promoted by increasing wheat bran 
dietary levels in the present experiment, this result was not statistically significant. According to Dänicke et al. (2000), soybean oil, which was included in T2 and T3, contain high oleic acid levels. Viveros et al. (2009) reported a decrease of serum triglyceride levels, explained by an increase of the activity of the enzyme lipoprotein lipase (LPL) in response to a higher inclusion level of oleic acid in the diet of the broilers. The higher crude fat percentage (Table 1) and consequent higher crude fat intake (Table 2) obtained with the T2 and T3 diets compared to T1 may have been balanced triglyceride levels, considering that soybean oil, which is rich in triacylglycerols, was not included in the control diet (T1). However, other experiments are needed to justify this hypothesis.

Serum phosphorus levels were not influenced by the treatments (Table 4), which was not expected, as WB is a viable source of phytases (Cavalcalti \& Behnke, 2004). Ali et al. (2008) reported an increase serum $P$ levels in broilers fed diets containing $300 \mathrm{~g} \mathrm{WB} / \mathrm{kg}$. The low phosphorus content of the experimental diets (Table 1) and the observed low $P$ intake may have influenced that result.

Likewise, blood calcium levels were not different among treatments (Table 4), possibly because the crude fiber intake (Table 2) was not excessive. High dietary fiber levels may cause retention of minerals and decrease their bioavailability, especially of calcium (Savón et al., 2007; Mateos et al., 2012).

\section{CONCLUSIONS}

The inclusion of $150 \mathrm{~g}$ wheat bran/ $\mathrm{kg}$ in partial replacement of corn in the diet of replacement laying pullets fed during the development phase (10 to 16 weeks) promoted better growth performance compared with 100 and $200 \mathrm{~g}$ wheat bran $/ \mathrm{kg}$. However, the inclusion of this cereal up to $200 \mathrm{~g} / \mathrm{kg}$ had no effect on organ weights or blood parameters.

\section{ACKNOWLEDGEMENTS}

This research study was supported by Chinese Academy of Sciences fellowship for young international scientist, under Grant No. 2011Y1SB07, Hunan Provincial Natural Science Foundation of China (13JJ2034), National Natural Science Foundation of China (313111032), Hunan Provincial Science and Technology Department (2014NK3048, 2014NK4134, 2014WK2032), and King Saud University, Deanship of Scientific Research, Addiriyah Chair for Environmental Studies.

\section{REFERENCES}

Aguilar Y, Yero O, Navarro M, Hurtado C, López J, Mejía L. Effect of squash seed meal (Cucurbita moschata) on broiler performance, sensory meat quality, and blood lipid profile. Brazilian Journal of Poultry Science 2011;13(4): 219-226.

Aho P. Impact on the world poultry industry of the global shift to biofuels. Poultry Science 2007;86(11): 2291-2294

Akhtar M, Tariq AF, Awais MM, lqbal Z, Muhammad F, Shahid M, Hiszczynska-Sawicka E. Studies on wheat bran Arabinoxylan for its immunostimulatory and protective effects against avian coccidiosis. Carbohydrate Polymers 2012;90(1):333-339.

Ali MN, Abou MS, El-kloub M. Incorporation of wheat bran in broiler diets. International Journal of Poulty Science 2008;7(1):6-13.

Castanon F, Leeper RW, Parsons CM. Evaluation of corn gluten feed in the diets of laying hens. Poultry Science 1990;69(1):90-97

Cavalcalti BW, Behnke CK. Effect of wheat bran phytase subjected to different conditioning temperatures on phosphorus utilization by broiler chickens based on body weight and toe ash measurements. International Journal of Poulty Science 2004;3(3):215-219.

Cherry JA, Jones DE. Dietary cellulose, wheat bran, and fish meal in relation to hepatic lipids, serum lipids, and lipid excretion in laying hen. Poultry Science 1982;61(9):1873-1878.

Connor WE, Johnston R, Lin DS. Metabolism of cholesterol in the tissues and blood of the chick embryo. The Journal of Lipid Research $1969 ; 10(4): 388-394$

Courtin CM, Broekaert WF, Swennen K, Lescroart O, Onagbesan O, Buyse J, Decuypere E, De Wiele T, Marzorati M, Verstraete W, Huyghebaert G, Delcour JA. Dietary inclusion of wheat bran arabinoxylooligosaccharides induces beneficial nutritional effects in chickens. Cereal Chemistry 2008;85(5):607-613.

Craeyveld VV, Dornez E, Holopainen U, Selinheimo E, Poutanen K, Delcour JA, Courtin MC. Wheat bran ax properties and choice of xylanase affect enzymic production of wheat bran-derived arabinoxylanoligosaccharides. Cereal Chemistry 2010;87(4):283-291.

Dänicke S, Böttcher W, Jeroch H, Thielebein J, Simon O. Replacement of soybean oil with tallow in rye-based diets without xylanase increases protein synthesis in small intestine of broilers. Journal of Nutrition 2000;130(4):827-834

Dridi S, Williams J, Bruggeman V, Onagbesan M, Raver N, Decuypere E, Djiane J, Gertler A, Taouis M. A chicken leptin-specific radioimmunoassay. Domestic Animal Endocrinology 2000;18(3):325-335.

Eastwood MA. The Physiological effect of dietary fiber:An update. Annual Review of Nutrition. 1992;12(10):19-35.

Eeckhaut V, Immerseel VF, Dewulf J, Pasmans F, Haesebrouck F, Ducatelle R, Courtin CM, Delcour JA, Broekaert WF. Arabinoxylooligosaccharides from wheat bran inhibit Salmonella colonization in broiler chickens. Poultry Science 2008;87(11):2329-2334.

Eswaran S, Muir J, Chey WD. Fiber and functional gastrointestinal disorders. The American Journal of Gastroenterology 2013;108(5):718-727.

FAO. Global and regional food consumer price inflation monitoring. Roman: The Statistics Division of the FAO; 2013 [cited 2014 Jan]. Available from: http://www.fao.org/fileadmin/templates/ess/documents/consumer/ CPI_Oct_2013.pdf

Font $\mathrm{H}$, Torres $\mathrm{V}$, Herrera $\mathrm{M}$, Rodríguez R. Fulfillment of the normality and the homogeneity of the variance in frequencies of accumulated 
measurement of the egg production variable in White Leghorn hens. Cuban Journal of Agricultural Science 2007;41(3):207-211.

González-Alvarado JM, Jiménez-Moreno R, Mateos GG. Effects of type of cereal, heat processing of the cereal, and inclusion of fiber in the diet on productive performance and digestive traits of broilers. Poultry Science 2007:86(8):1705-1715.

Gorter H, Drabik D, Just DR, Kliauga EM. The impact of OECD biofuels policies on developing countries. Agricultural Economics 2013;44(4):477-486.

Hetland H, Svihus B, Krogdahl A. Effects of hoat hulls and wood shavings on digestion in broilers and layers fed diets based on whole or ground wheat. British Poultry Science 2003;44(2):275-282.

Hyatt D, Irwin L, Lee J, Lyons J. Poultry nutrition. In: Hyatt D, editor. Poultry science manual. Texas: Instructional Materials Service; 2012. p. 1-13.

Jørgensen $\mathrm{H}$, Zhao XQ, Knudsen KEB, Eggum BO. The influence of dietary fiber source and level on the development of the gastrointestinal tract, digestibility and energy metabolism in broiler chickens. Brithish Journal of Nutrition 1996(3);75:379-395.

Kahlon TS, Berrios JJ, Smith GE, Pan JL. Extrusion conditions modify hypocholesterolemic properties of wheat bran fed to hamsters. Cereal Chemistry 2006;86(2):152-156.

Kahlon TS, Edwards RH, Chow Fl. Effect of extrusion on hypocholesterolemic properties of rice, oat, corn, and wheat bran diets in hamsters. Cereal Chemistry 1998;76(6):897-903.

Latshaw JD. Daily energy intake of broiler chickens is altered by proximate nutrient content and form of the diet. Poultry Science 2008;87(1):8995.

Lefevre M, Mensink RP, Kris-Etherton PM, Petersen B, Smith K, Flickinger $\mathrm{BD}$. Predicted changes in fatty acid intakes, plasma lipids, and cardiovascular disease risk following replacement of trans fatty acidcontaining soybean oil with application-appropriate alternatives. Lipids 2012;47(10):951-962.

Martínez M, Savón L, Dihigo LE, Hernández Y, Oramas, A, Sierra F, et al. Cecal and blood fermentative indicators in broiler chickens fed Morus alba foliage meal in the ration. Cuban Journal of Agricultural Science 2010;44(1):49-53.

Martínez M, Savón L. Leptin, key hormone in regulation of feed intake and energy balance of animal body. Cuban Journal of Agricultural Science 2007;39(1):3-12

Martínez Y, Caicedo J, Rodríguez R, Chica J, Liu G, Betancur C. Growth performance, carcass traits and lipid profile of broiler chicks fed with an exogenous emulsifier and increasing levels of energy provided by palm oil. Journal of Food, Agriculture and Environment 2013b;13(1):629633.

Martínez Y, Martínez O, Liu G, Ren W, Rodríguez R, Fonseca Y, et al. Effect of dietary supplementation with Anacardium occidentale on growth performance and immune and visceral organ weights in replacement laying pullets. Journal of Food, Agriculture and Environment 2013a:13(4):1352-1357.
Mateos GG, Jiménez-Moreno E, Serrano MP, Lázaro RP. Poultry response to high levels of dietary fiber sources varying in physical and chemical characteristics. Journal Applied Poultry Research 2012;21(10):156-174.

Mcnaughton JL. Effect of dietary fiber on egg yolk, liver, and plasma cholesterol concentrations of the laying hen. Journal of Nutrition 1978;108(11):1842-1848

NRC- National Research Council. Nutrient requirements of poultry. 9th ed. Washington: Academy Press; 1994

Okazaki H, Tazoe F, Okazaki S, Isoo N, Tsukamoto K, Sekiya M, et al. Increased cholesterol biosynthesis and hypercholesterolemia in mice overexpressing squalene synthase in the liver. The Journal of Lipid Research 2006:47(9):1950-1958.

Olmo C, Martínez Y, León E, Leyva L, Nuñez M, Rodríguez R, et al. Effect of mulberry foliage (Morus alba) meal on growth performance and edible portions in hybrid chicken. International Journal of Animal and Veterinary Advvances 2012;4(4):263-268.

Rieckhoff D, Trautwein EA, Mälkki Y, Erbersdobler HF. Effects of different cereal fibers on cholesterol and bile acid metabolism in the syrian golden hamster. Cereal Chemistry 1999;76(5):788-795.

Rodríguez R, Cisneros M, Valdivié M, Martínez M, Sarduy L. Morphometry of the gastrointestinal tract and its accessory organs in laying hens fed feedstuffs containing proteinic sugarcane meal. Cuban Journal of Agricultural Science 2006;40(3):361-365.

Rosebrough RW, Mcmurtry JP, Vasilatos-Younken R. Dietary fat and protein interactions in the broiler. Poultry Science 1999;78(7):992-998.

Sacranie A, Svihus B, Denstadli V, Moen B, lij PA, Choct M. The effect of insoluble fiber and intermittent feeding on gizzard development, gut motility, and performance of broiler chickens. Poultry Science 2012;91(3):693-700

Savón L, Scull I, Martínez M. Integral foliage meal for poultry feeding. Chemical composition, physical properties and phytochemical screening. Cuban Journal of Agricultural Science 2007:41(2):359-361.

Shyama PR, Muralikrishna G. Non-starch polysaccharide-phenolic acid complexes from native germinated cereals and millet. Food Chemistry 2004;84(4):527-531.

UECAN - Unión de Empresas del Combinado Avícola Nacional. Manual Tecnológico para la cría de aves. Ponedoras y sus reemplazos. 5th ed. Habana: MINAG; 2011

Vieira S L, Lemme A, Goldenberg D, BBrugalli I. Responses of growing broilers to diets with increased sulfur amino acids to lysine ratios at two dietary protein levels. Poultry Science 2004;83(8):1307-1313.

Viveros A, Brenes A, Pizarro $M$, Castano $M$. Effect of enzyme supplementation of a diet based on barley, and autoclave treatment, on apparent digestibility, growth performance and gut morphology of broilers. Animal Feed Science and Technology 1994;48(3):237-251.

Viveros A, Ortiz LT, Rodríguez ML, Rebole A. Interaction of dietary higholeic-acid sunflower hulls and different fat sources in broiler chickens. Poultry Science 2009;88(1):141-151. 

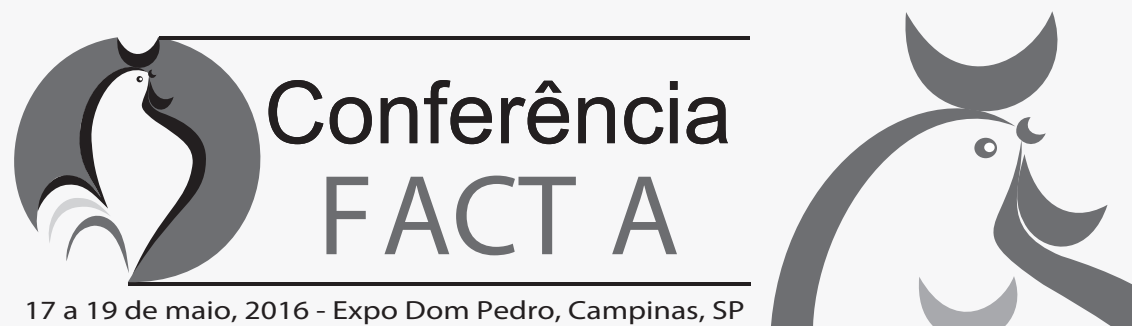

Avicultura

Sustentável

Realização:
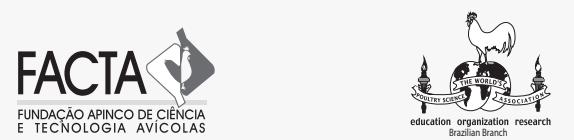

$\underset{\substack{\text { SANE } \\ \text { THE DATE }}}{\cos }$

17 a $19 \div$

MAIO유 